\title{
SUBMICROSCOPIC STRUCTURE OF THE HUMAN JOINT CARTILAGE AND SYNOVIAL MEMBRANE IN OCHRONOSIS
}

\author{
D. HORKÝ \\ Department of Morphology, University of Veterinary Science, 61242 Brno
}

Received October 8, 1980

\begin{abstract}
Horký D.: Submicroscopic Structure of the Human foint Cartilage and Synovial Membrane in Ochronosis. Acta vet. Brno, 50, 1981: 131-156.

Using a transmission electron and scanning electron microscope the joint cartilage and synovial membrane were studied in 5 persons of the age from 30 to 55 years.

In its majority the superficial cartilage layer is absent due to arthritic changes caused by the deposition of granules of ochronotic pigment in the intercellular substance of the cartilage. In regions with a well-preserved cartilage distinct sings of arthrosis are evident on its surface. In the cytoplasm of chondrocytes of the middle layer vesicles appear filled with ochronotic pigment in various stages of polymerization. The aperiodic fibres which penetrate into the proximity of the chondrocytes multiply so that the pericellular matrix disappears. A small amount of granules of the ochronotic pigment is deposited in this area, whereas in the intercellular matrix they appear in a large amount both in the form of granules and in layers deposited between thick collagen fibres. In the deep layer there are signs of degeneration of chondrocytes. In the cytoplasm autophagic vacuoles occur formed by pigment granules, secondary lysosomes, lipid droplets and concentrically layered membranes of the granular endoplasmic reticulum. In the scanning electron microscope deep defects are distinctly evident on the surface and empty chondrocyte capsules with mound-like contoured edges. Both on the bottom of these capsules and on the surface of the cartilage deposited are crystals of ochronotic pigment, cell debris and solitary cells. Short sections of the synovial membrane are covered with a confluent layer of cells of a transient type. No pigment occurs in the thus arranged synovial membrane. The major part of the synovial membrane surface is pigment with a layer of intercellular substance in which granules of ochronotic covered are deposited. Nearer to the surface the synovialocytes resemble fibrocytes and small amounts of granules of pigment occur in their cytoplasm. Synovialocytes situated deeper are of intermediary type and in their cytoplasm pigment is deposited in the form of large deposits of as much as $2 \mu \mathrm{m}$ in size.
\end{abstract}

Man, ochronosis, joint cartilage, synovial membrane, ochronotic pigment.

Alkaptonuria is a relatively rare disorder of amino acid metabolism with recessive heredity characterized by the excretion products of urine degradation. In some cases homogentisic acid is one of the products of this degradation deposited in tissues. This condition is defined as ochronosis. The disease is caused by a defect of oxidase of homogentisic acid (La Du et al. 1958, 1966) and the disorder occurs in tyrosine metabolism.

Ochronosis was described for the first time by Virchow (1866) on necrotic material. In 1922 Albrecht recognized the connection between alkaptonuria and ochronosis. Following this period a number of studies were published dealing with this disorder of tyrosine metabolism. A review of biochemical aspects of the disease and its clinical manifestations is given in the studies of Cerveňanský et al. (1959) and Jaffe (1972).

Morphological data are incomparably rarer. The first more detailed information was given by Pope (1906) - see Laskar and Sargison (1910). Kleinschmidt (1922), Garrod (1923), Hertzburg (1945), Lichtenstein and Kaplan (1954), Cooper and Moran (1957), O'Brien 
et al. (1963), McCollum and Odom (1965), Laskar and Sargison (1970) informed about arthrotic changes and fragmentation of joint cartilage in ochronosis.

Surprisingly few studies exist on the electron microscopic level. Most knowledge about the ultrastructure of the synovial membrane in ochronosis can be found in studies by Kutty et al. (1973, 1974), Regin a to et al. (1973), Bozděch et al. (1975), Fassbender et al. (1975) dealing with the ultrastructure of joint cartilage and partly also of synovial membrane. Besides this, partial information was published in the studies of Hirohata and Morimoto (1971), Pages and Baldet (1971). Fuchs (1968) studied the ultrastructure of ochronotic pigment and possibilities of its differentiation from the pigment granules of different provenience. Attwood et al. (1974) and Daicker and Ried (1974) described changes in cells during the deposition of ochronotic pigment into other tissues than joint ones. Cases were observed of experimentally evoked ochronosis after intoxication with phenol or its derivatives (Oppenheimer and Kline 1922, Bondurant 1965) which was described on the ultrastructure level by Mihatsch et al. (1973).

\section{Materials and Methods}

For studies of the ultrastructure of the joint cartilage and synovial membrane in a transmission electron microscope samples of these tissues were taken from 5 patients of 30-55 years of age. The material was taken from the hip joints with total endoprostheses. Both from the joint cartilage and synovial membrane $1 \times 1 \times 2 \mathrm{~mm}$ strips were taken. Cartilage samples were fixed in $3 \%$ or $4 \%$ glutaraldehyde in a phosphate buffer at $\mathrm{pH} 7.4$, decalcified in $0.1 \mathrm{M}$ EDTA with $4 \%$ glutaraldehyde at $\mathrm{pH} 7.4$. The blocks were then rinsed in $0.1 \mathrm{M}$ phosphate buffer at $\mathrm{pH} 7.4$, the samples were post-fixed with $1 \% \mathrm{OsO}_{4}$ according to Millonig in a phosphate buffer at $\mathrm{pH} 7.4$.

Samples of synovial membrane were all fixed with 3\% glutaraldehyde at $\mathrm{pH} 7.4$, the tissue was

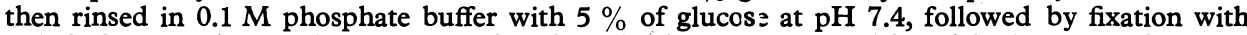
$1 \% \mathrm{OsO}_{4}$ according to Millonig in phosphate buffer at $\mathrm{pH} 7.4$. After dehydration with acetone, or alcohol, the material was embedded into Durcupan ACM or Epon-Araldit.

Ultrathin sections were made on Tesla BS 490, Reichert Omu 3 and LKB Ultrotome III ultramicrotomes and stained with lead citrate or with $1 \%$ uranylacetate and then lead citrate. The sections made were examined and photographed with Tesla BS 613 and Tesla BS 500 electron microscopes.

For studies of the surface of the joint cartilage and synovial membrane under a scanning electron microscope $5 \times 5 \mathrm{~mm}$ samples were taken and left for $3-4$ hours before fixation in a solution of hyaluronidase in a concentration of $0.1 \mathrm{mg} / \mathrm{ml}$ at a temperature of $4^{\circ} \mathrm{C}$. The samples were post-fixed with $10 \%$ formol or glutaraldehyde, dehydrated, coated with gold or platinum on a Balzers coating apparatus and studied with a Stereoscan Cambridge scanning electron microscope.

The material was elaborated at the Department of Histology and Embryology of the Faculty of Medicine, J. E. Purkyně University, Brno.

\section{Results}

\section{Submicroscopic structure of the cartilage}

The submicroscopic structure of the joint cartilage in ochronosis is greatly affected by the arthrotic process appearing mostly in the superficial layer due to fibrillation and gradual destruction of the intercellular substance followed by chondrocyte degeneration. Damage of the cartilage is caused by deposition of deposits of ochronotic pigment in the intercellular substance and in the cells.

\section{Superficial layer}

Due to arthrotic changes the superficial layer of the cartilage is mostly absent and the surface is covered by a connective tissue with large amount of celles. The ground fibrillar substance is represented only by solitary collagen fibres deposited in the abundant ground amorphous substance. Together with projections of fibrocytes it forms a more compact layer of various thickness on the surface. No ochronotic pigment was found in this tissue.

In regions where the cartilage is partly preserved, common signs of arthrosis can be observed on its surface (Fig. 1). The chondral membrane is considerably 


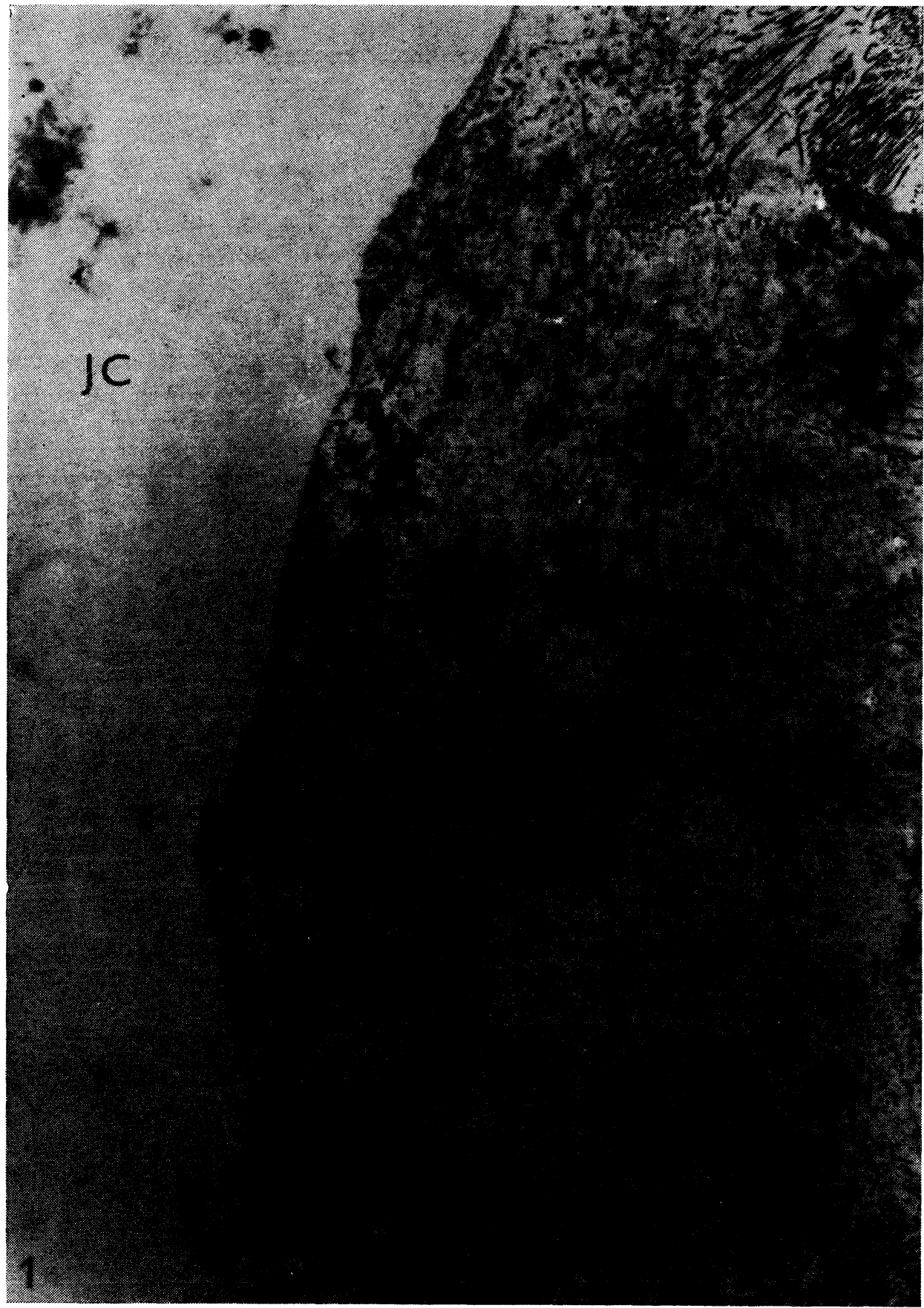

Fig. 1.

Region of preserved joint cartilage in ochronosis. Remains of thinned chondral membrane (m), collagen fibres $(\mathrm{K})$ penetrate to the surface and are revealed. Regional disappearance of the ground amorphous substance occurs (za). Joint cavity (JC). $11000 \times$. 
reduced or is completely absent. Collagen fibres penetrate both individually and in bundles to the cartilage surface and are thus denuded. Chondrocytes do not occur in the superficial layer.

\section{Middle layer}

The ultrastructure of chondrocytes in the middle layer is surprisingly well preserved both in the connective tissue-covered area as well as in the area of intact joint cartilage. As in a normal cartilage the chondrocytes are deposited in capsules either individually or in pairs and they reach the same size.

\section{a) The nucleus}

is mostly oval in shape. The structure of the nuclear envelope is usual and protrudes in wide shallow invaginations against the karyoplasm. Nuclear chromatin is arranged into karyosomes at the nuclear membrane and on the nuclear section further clusters are evident localized in the karyoplasm. In contradistinction to chondrocytes of the same layer of a normal cartilage no zonula nucleum limitans is formed (Fig. 2). The nucleolus is a rare finding. Provided it is present, pars fibrosa and pars granulosa segregation are evident.

a) Cytopiasm

a) Cell organellae

Granular endoplasmic reticulum is formed by flattened cisternae, oriented parallelly with the surface of the nucleus. Some of the cisternae are strikingly dilated and contain finely granulated, electron transparent material (Fig. 2, 3).

Agranular endoplasmic reticulum as to its amount and size of vesicles does not differ from this organella occurring in the cytoplasm of a normal joint cartilage.

The Golgi complex occurs regularly. It is abundantly developed and in the cytoplasm is deposited into several fields. In some cases it forms a large region and from its smooth cisternae dispersed in a club-like way larger amounts of small and large vesicles are separated some of which are empty, others contain a fine granular, moderately osmiophilic substance (Fig. 3).

Mitochondria are as frequent as in the normal cartilage. In some cells damaged mitochondria can be found with fragmented cristae and regions of clearer matrix. These are obviously decaying mitochondria (Fig. 2,3).

Secondary lysosomes occur in the cytoplasm of the chondrocytes of the middle layer of the ochronotic cartilage in the same amounts as in the normal cartilage and they do not differ in size or structure (Fig. 2, 3).

$\beta$ ) cytoplasmic inclusions

Lipid droplets are rare and provided they do occur they are deposited near cytolysomes.

Glycogen is of the same appearance and localization as in the normal cartilage Fig. 2, 3).

Fig. 2.

Part of chondrocyte of middle layer of joint cartilage in ochronosis. Nucleus (N), granular endoplasmic reticulum (E), mitochondria (M), glycogen (g), lysosomes (L), cytoplasmic processes (c). In the place of the pericellular matrix are bundles of aperiodic fibrils (a), in the intexcellular matrix (I) granules of ochronotic pigment (O). $14000 \times$. 


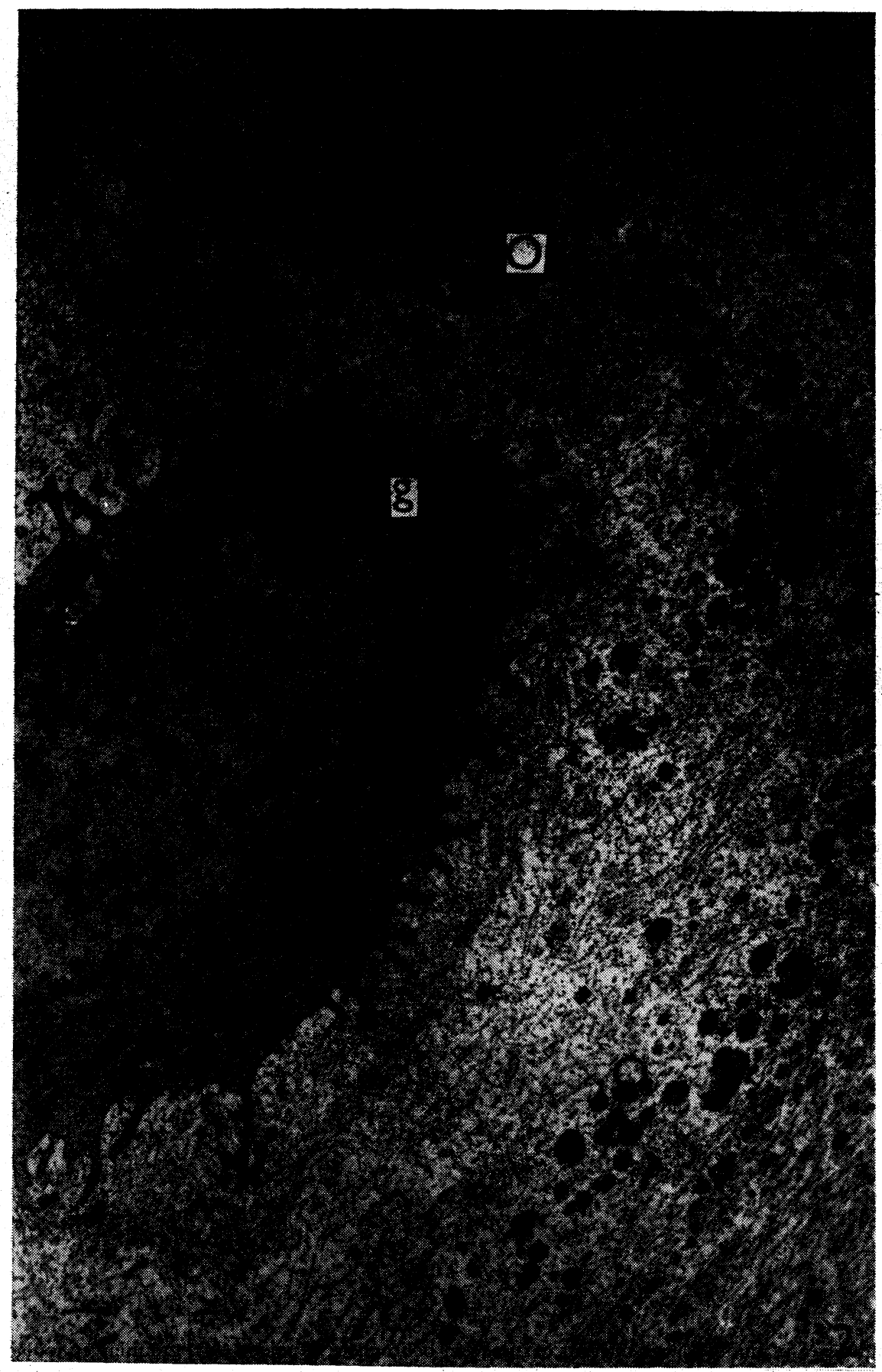




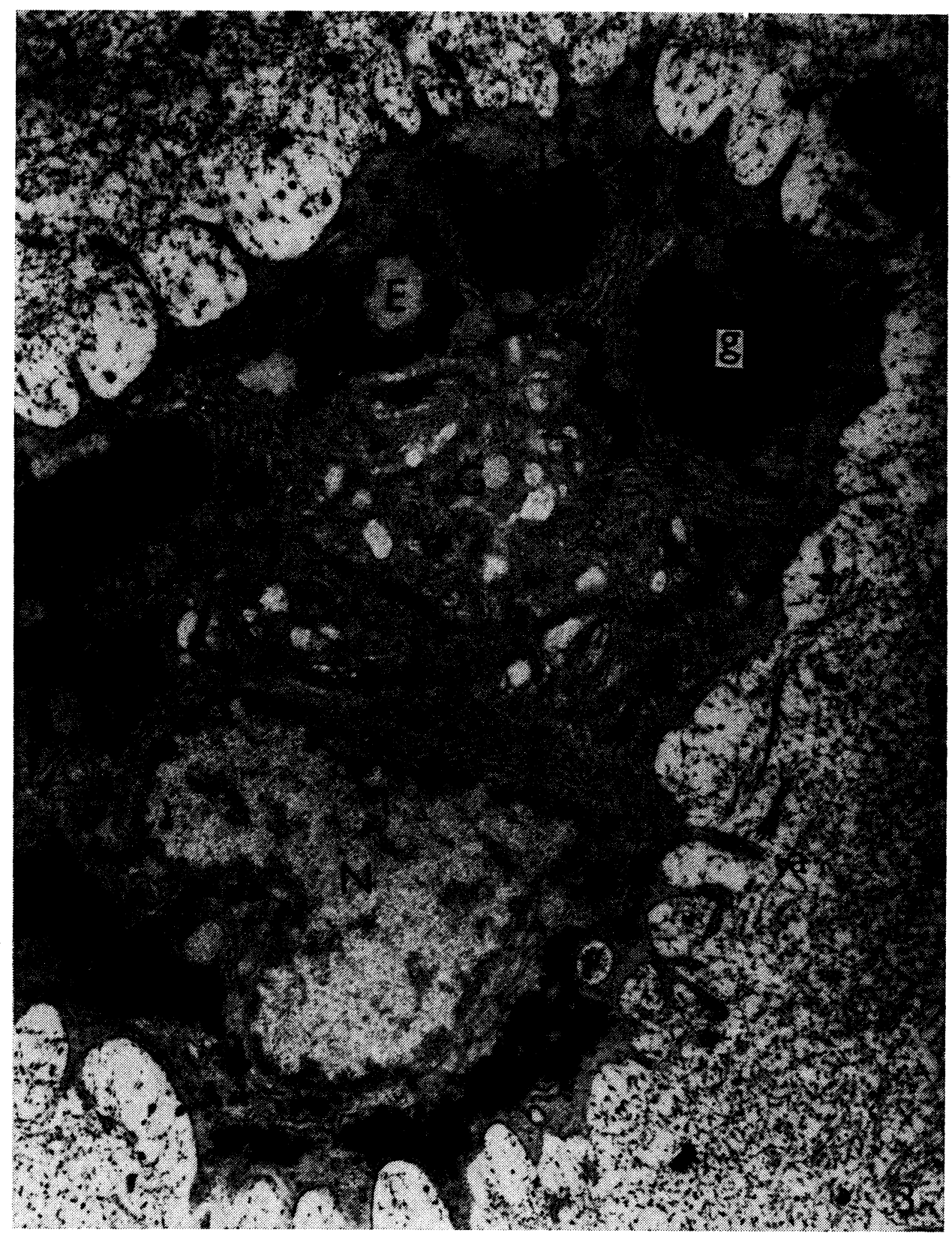

\section{Fig. 3.}

Chondrocyte of middle layer of joint cartilage in ochronosis. Nucleus $(\mathrm{N})$, granular endoplasmic reticulum (E) with dilated cisternae. Developed Golgi complex (G) with vesicles filled with granulated mass, mitochondria (M), lysosomes (L), glycogen (g). Bundles of aperiodic fibrils (a), vesicles with ochronotic pigment (v). $16500 \times$. 
A new structure appearing in the cytoplasm of chondrocytes of the middle layer are vesicles enclosed by a smooth membrane containing ochronotic pigment in different stages of polymerization. The vacuoles are filled with clear, fine granular or electron-dense material. The result of the process of "condensation" of the content are dark corpuscles, enclosed by a membrane, of about, $0.5-0.7 \mu \mathrm{m}$ deposited as a rule in the proximity of the nucleus. Possibly also the material of pinocytotic vesicles is transmitted into these vacuoles (Fig. 2,3).

Cytoplasmic fibrillar structures - in contradistinction to chondrocytes of the same layer of the normal cartilage they were not observed in ochronotic cartilage.

\section{$\gamma$ ) Cell surface}

The cytoplasm protrudes into the pericellular matrix in numerous short cytoplasmic processes. Their length does not exceed $1 \mu \mathrm{m}$ and their width ranges from 0.2 to $0.5 \mu \mathrm{m}$. Pinocytotic vesicles are not very numerous as compared with the normal cartilage and if observed some of them contain material of the same appearance that later occurs in large vesicles deeper in the cytoplasm (Fig. $2,3)$.

\section{Deep layer}

Chondrocytes in this layer are deposited in the same way as in the deep layer of the normal cartilage. Cells of this layer differ from chondrocytes in the normal cartilage due to degeneration processes which largely afect them.

\section{a) The nucleus}

shrinks; either it is the thickening of nuclear chromatin, or chromatin is arranged into a dark strip by the inner membrane of the nuclear envelope, the remaining area of the nucleus being strikingly light. The zonula nucleum limitans is not formed. The nucleolus, provided it occurs, is of reticular structure (Fig. 4).

a) Cytoplasm

a) Cell organellae

Granular endoplasmic reticulum in the chondrocytes of the deep layer of the joint cartilage in ochronosis is differently arranged. In the majority of cells its cisternae are enormously dilated so that they form large vesicles filled with moderately osmiophilic, fine granular material. In other cases its cisternae are concentrically layered and they surround the area of ground cytoplasm with secondary lysosomes, and/or deposits of ochronotic pigment. In appearance they resemble autophagic vacuoles even though they are not yet enclosed by a smooth membrane (Fig. 4).

Agranular endoplasmic reticulum is arranged in the same way as in cells of the deep layer of a normal cartilage.

The Golgi complex is well formed in those cells which show no signs of degeneration and where no dilatation of cisternae of the granular endoplasmic reticulum occurs. In these cases the Golgi complex is dispersed into several fields which occupy a relatively large part of the cytoplasm. If dilatation of the cisternae of the granular endoplasmic reticulum in cells occurs, the Golgi complex is reduced in number losing its characteristic arrangement and it consists of solitary flat vesicles and a large number of small vesicles (Fig. 4). 


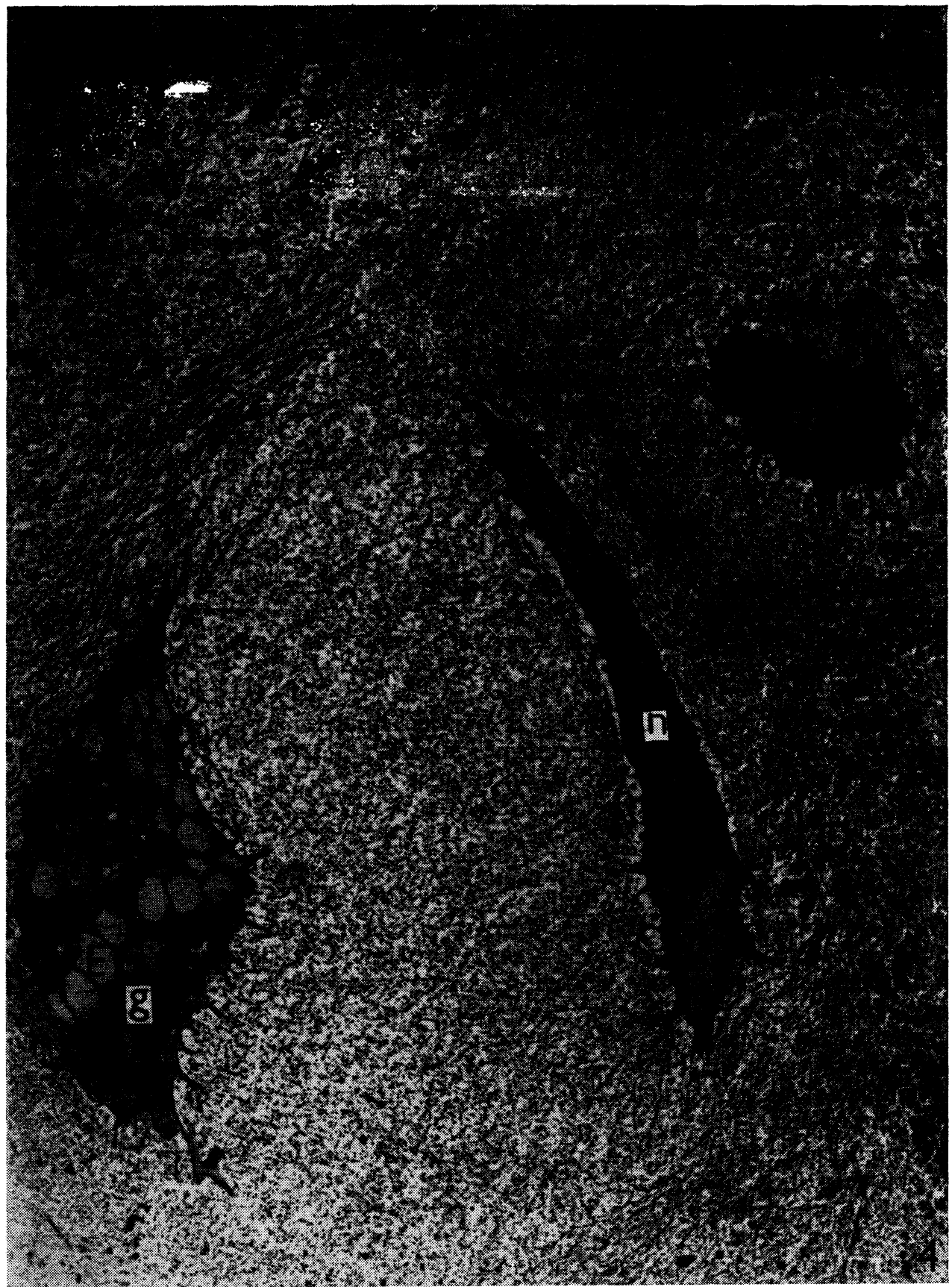


Mitochondria are not very frequent and the majority of them show signs of damage beginning with the fragmentation of cristae up to their disappearance. Clear districts occur in the mitochondrial matrix. Single inner mitochondrial membrane forms circular formations resembling pseudomyelin figures.

Lysosomes occur in the cytoplasm of chondrocytes of the deep layer of ochronotic cartilage more frequently than in the normal cartilage. They appear as vesiccles of as much as $1 \mu \mathrm{m}$ in size and are filled with granular or homogenous electron-dense material. As a rule, they are accumulated in one region of the cytoplasm together with granules of ochronotic pigment (Fig. 4).

\section{$\beta$ ) Cytoplasmic inclusions}

Lipid droplets occur only scarcely as in chondrocytes of a normal cartilage. Glycogen in contrast to the normal cartilage occurs in the cytoplasm of this layer of ochronotic cartilage in much larger amounts. Glycogen granules of a size of about $40 \mu \mathrm{m}$ form clusters occupying a relatively large area on the sections. Along with large deposits also smaller clusters occur, deposited between the dilated cisternae of the granular endoplasmic reticulum (Fig. 4).

Ochronotic pigment is present in the cytoplasm on the one hand as dark corpuscles enclosed by a membrane of a size of about $0.1-0.2 \mu \mathrm{m}$ and, on the other hand, as larger vesicles of about $1 \mu \mathrm{m}$. deposited either individually in the cytoplasm or together with lysosomes in the autophagic vacuole formed inside.

r) Cell surface

The cell surface is formed differently in chondrocytes of a polyedric or oval shape and in expressively flattened cells. In the former type of cells the surface is arranged in the same way as in the normal cartilage as far as the length of the processes and their shape are concerned. In flattened cells the cytoplasmic processes are not numerous, the cellular membrane runs with no larger unevennesses and only on both cell poles it protrudes in several short unramifying processes. Pinocytotic vesicles occur only rarely (Fig. 4).

Cilia were a unique finding; they occurred only in one case in the cytoplasm of chondrocytes of this cartilage layer.

\section{Submicroscopic stru'cture of the intercellijular substance}

The ground fibrillar substance is represented by collagen fibrils of two appearances. On the one hand they are collagen fibres $80-120 \mu \mathrm{m}$ thick with a typical periodicity of $64 \mu \mathrm{m}$, on the other hand fibrils 40 and $20 \mu \mathrm{m}$ thick. The periodicity is evident even in fibres $40 \mu \mathrm{m}$ thick but is not evident in fibres $20 \mu \mathrm{m}$ wide (Fig. 5).

The appearance of the ground amorphous substance under great enlargement is irregularly net-like. In the place of contact of several fibrillar structures of the

Fig. 4.

Group of chondrocytes of deep layer of joint cartilage in ochronosis. Nucleus $(\mathrm{N})$ with thickened chromatin, nucleolus ( $\mathrm{n}$ ). Dilated cisternae of granular endoplasmic reticulum (E), damaged structures of the Golgi complex (G), glycogen deposits $(\mathrm{g})$. In the area of the pericellular matrix are bundles of aperiodic fibres (a), in the intercellular matrix granules of ochronotic pigment $(\mathrm{O})$. 


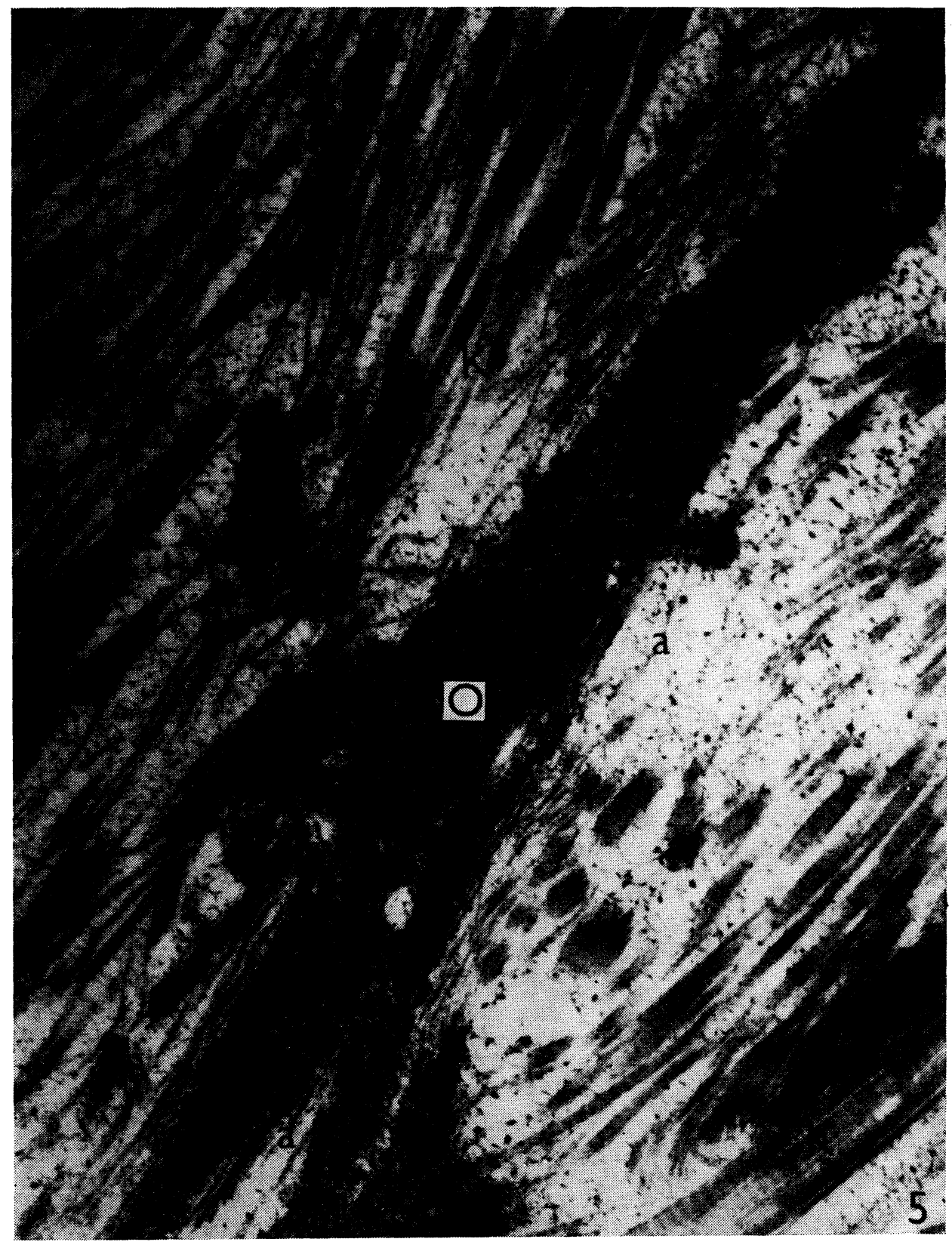

Fig. 5.

Intercellular substance of joint cartilage in ochronosis. Collagen fibres $(\mathrm{K})$ with typical periodicity, aperiodic fibres (a). Between the collagen fibres a layer of ochronotic pigment $(\mathrm{O})$, partly masking the fibres. $35000 \times$. 
ground amorphous substance (originated through precipitation of the protein component of the amorphous substance) an electron-dense concentrated area appears. Under small and medium enlargement the appearance of the ground amorphous substance is an irregularly arranged net or regions of a moderately osmiophilic, fine granular material.

Pigment is deposited into the intercellular substance of the joint cartilage in alkaptonuria. It occurs as extensive deposits composed of granules of different size reaching $1 \mu \mathrm{m}$ and more. They are deposited in the ground amorphous substance and are not enclosed by a membrane. On their surface precipitation often occurs; probably of proteins of the ground amorphous substance in the form of strongly osmiophilic granules which can imitate the membrane structure; however, under great enlargement it is evident that the pigment is not enclosed by a membrane (Fig. 2, 3, 4).

Arrangement of the ground fibrillar substance in the intercellular cartilage substance

As given above the superficial layer of the cartilage is in its majority covered by connective tissue. The fibrillar component, in this case, is represented only by single collagen fibres deposited in the relatively abundant ground amorphous substance. In regions where the cartilage is preserved, the chondral membrane becomes thinned or even disappears. Collagen fibres penetrate both individually and in bundles to the cartilage surface and are denuded (Fig. 1).

In the middle and deep layers of the intercellular substance the fibrillar cartilage component in ochronosis is arranged in the same way and differs from the normal cartilage. The greatest difference lies in the disappearance of the pericellular matrix so that the border betwen the chondrocyte capsule proper and the intercellular matrix is not evident (Fig. 2,3). Collagen fibres penetrate into the close vicinity of the cell membrane of the chondrocytes and only in some cases can a greater "halo" be observed indicating the area of the original capsule. The region of pericellular matrix is completely absorbed by the aperiodic collagen fibres (Fig. 4). Granules of the ochronotic pigment penetrate to the chondrocytes from where they can be transported into the cytoplasm. The largest amount of pigment granules is deposited in the intercellular matrix, whereas in the area of the original capsule they participate much more rarely (Fig. 2, 4). The disappearance of the pericellular matrix and the irregular course of the collagen fibres is problably due to the deposition of the ochronotic pigment into the ground cartilage substance and decreased synthetic activity of chondrocytes connected with manifestations of cell degeneration.

\section{Joint cartilage surface in the scanning electron microscope}

When studying the surface of the joint cartilage we aimed mainly at the area which was not covered by connective tissue because only here could we obtain a picture of its appearance, whereas in the region covered by connective tissue the appearance is not much expressive and its study could not bring forth new knowledge about the appearance of the deeper deposited cartilage.

The surface of the joint cartilage in the scanning electron microscope is expressively furrowed. Deep defects are distinctly evident onto which flatter incisions are oriented almost vertically (Fig. 6). Ochronotic pigment is deposited mainly 


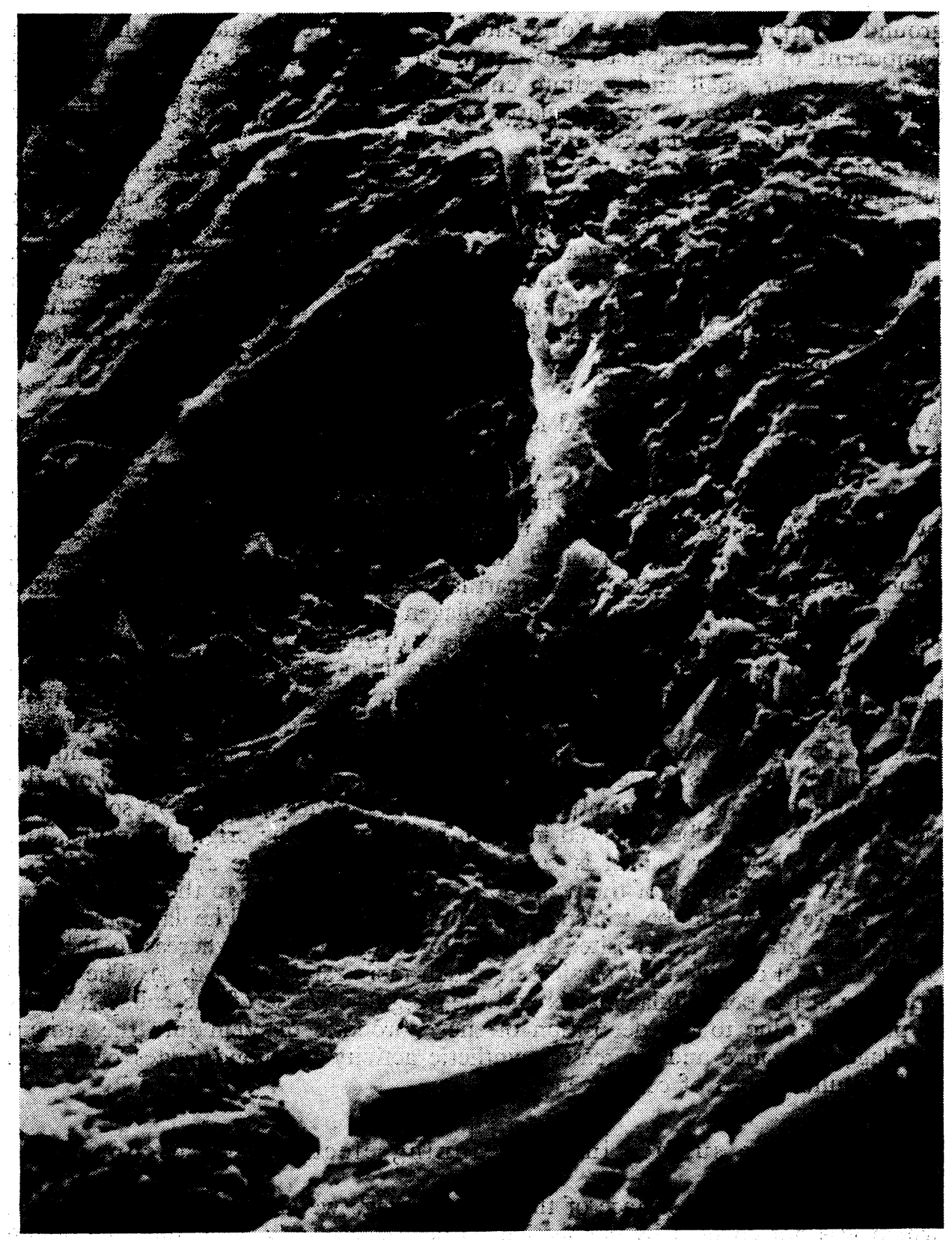

Fig. 6.

Circular depression from the surface of the ochronotic joint cartilage with mould-like thickened edge. In the depression erythrocytes (b) and ochronotic pigment (0), which is evident also on the surface outside the depression. Scanning electron microscopy. $5600 \times$. 


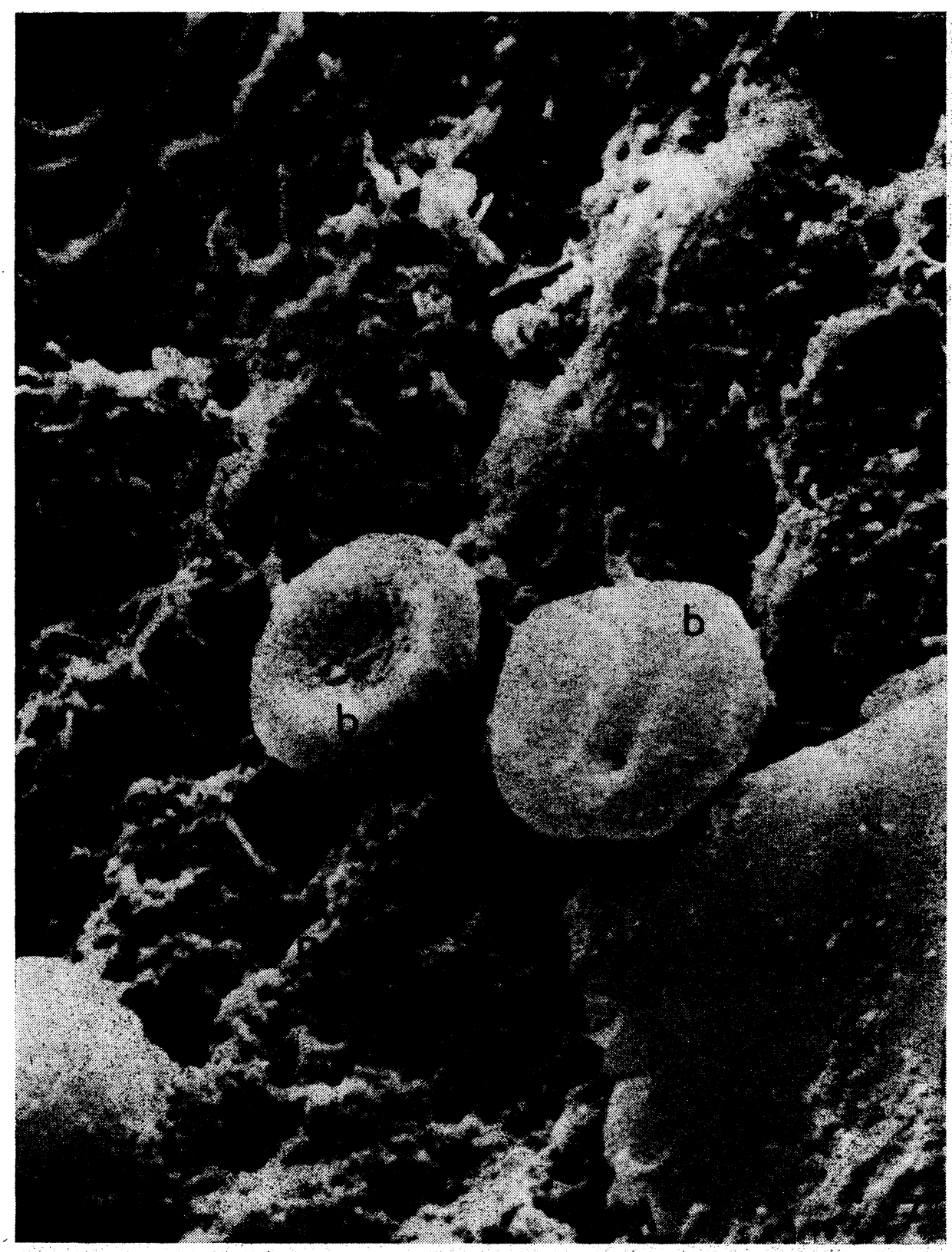

Fig. 7.

Part of the arthrotic joint cartilage in ochronosis under great magnification. Distinct is the uneven surface with fragments of revealed collagen fibres $(\mathrm{K})$, crystals of ochronotic pigment $(\mathrm{O})$, erythrocytes (b) and overgrowing connective tissue on the edge. $28700 \times$. 


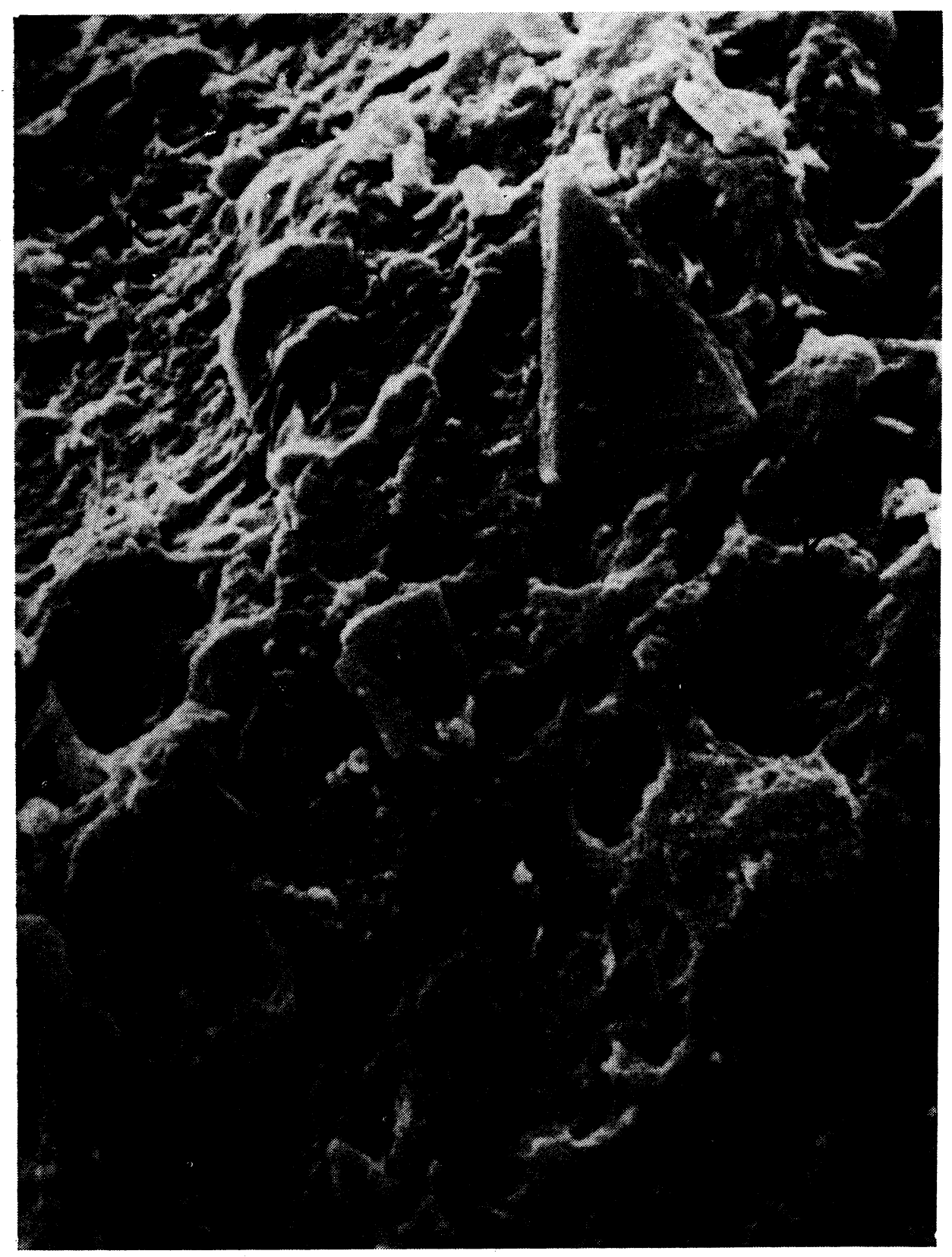

Fig. 8.

Part of the surface of arthrotic changed joint cartilage in ochronosis. Changed texture of the cartilage with free bundles of collagen fibres $(K)$ and crystals of ochronotic pigment $(\mathrm{O})$. Scanning electron microscopy. $12550 \times$. 
in the deep defects in the form of platelets with irregular edges. In addition, rounded defects are demonstrated, surrounded by a rather big mound. On their bottom erythrocytes, cell debris and crystals of ochronotic pigment occur (Fig. 7). The rounded defects mentioned above correspond in their size with the size of chondrocytes and according to the author's opinion they are empty capsules of degenerated cells. On some places of the joint cartilage surface the chondral membrane is preserved to a larger extent; however, the surface is strongly furrowed and covered with crystals of ochronotic pigment, cell debris and singular macrophages (Fig. 8). The bases of cristae protruding above the cartilage surface are folds formed by the chondral membrane because, according to observations in the scanning electron microscope, we cannot prove the presence of large bundles of collagen fibres in this layer. Serious arthrotic changes appear on the joint cartilage surface, on the one hand due to fibrillation of the intercellular substance when bundles of collagen fibres can be observed freely protruding from the edges of the defect and, on the other hand, in empty chondrocyte capsules. On the surface of the strongly furrowed cartilage fragments of collagen fibres, crystals of ochronotic pigment of various size, and singular erythrocytes can be found. In some cases both the furrows and cristae are partly covered by the overgrowing connective tissue.

\section{Submicroscopic structure of the synovial membrane}

In ochronosis the synovial membrane has a regionally very different appearance which is a very surprising finding. In some parts its surface runs without any major irregularities and towards the joint cavity it is enclosed by a consistent layer of cells which do not transmit cytoplasmic processes. The cells cannot be distinguished into types A and B. They are intermediary types similar in their ultrastructure to A cells, whereas B cells occur only very rarely. Under this continuous layer of cells orientated by a longitudinal axis with the surface of the synovial membrane, further cells in the intercellular substance are irregularly deposited. The shape of cells of the deeper layer are most frequently star-like with numerous cytoplasmic projections directed towards the deeper layers of the synovial membrane. The synovial surface is not smooth, various deep depressions and processes can be observed on it caused by the villous formed synovial membrane or individual cells protruding above the surface of the surrounding synovialis. Free cells from the joint cavity are attached to the surface, namely erythrocytes. These elements are phagocytized by the cells of the synovial membrane (Fig. 9). With the exception of the synovial membrane of the appearance described which occupies small regions the arrangement of the majority is quite different.

In this case the synovialis surface is covered by a rather thick layer of intercellular substance with numerous collagen fibres often arranged into bundles. The majority of the collagen fibres and bundles runs parallel to the surface and on the sections they are longitudinal, transverse and tangential. The ground amorphous substance does not form a consistent cover towards the joint cavity, often it is completely absent so that the collagen fibres are exposed (Fig. 10). In the intercellular substance of the superficial layer particles of ochronotic pigment occur in rather small amounts. Synovial cells are deposited deeper under the surface of the synovial membrane, most frequently in several layers above each other and according to the fine structure they can be divided into cells deposited more towards the surface resembling fibrocytes in appearance and the deeper deposited syn- 


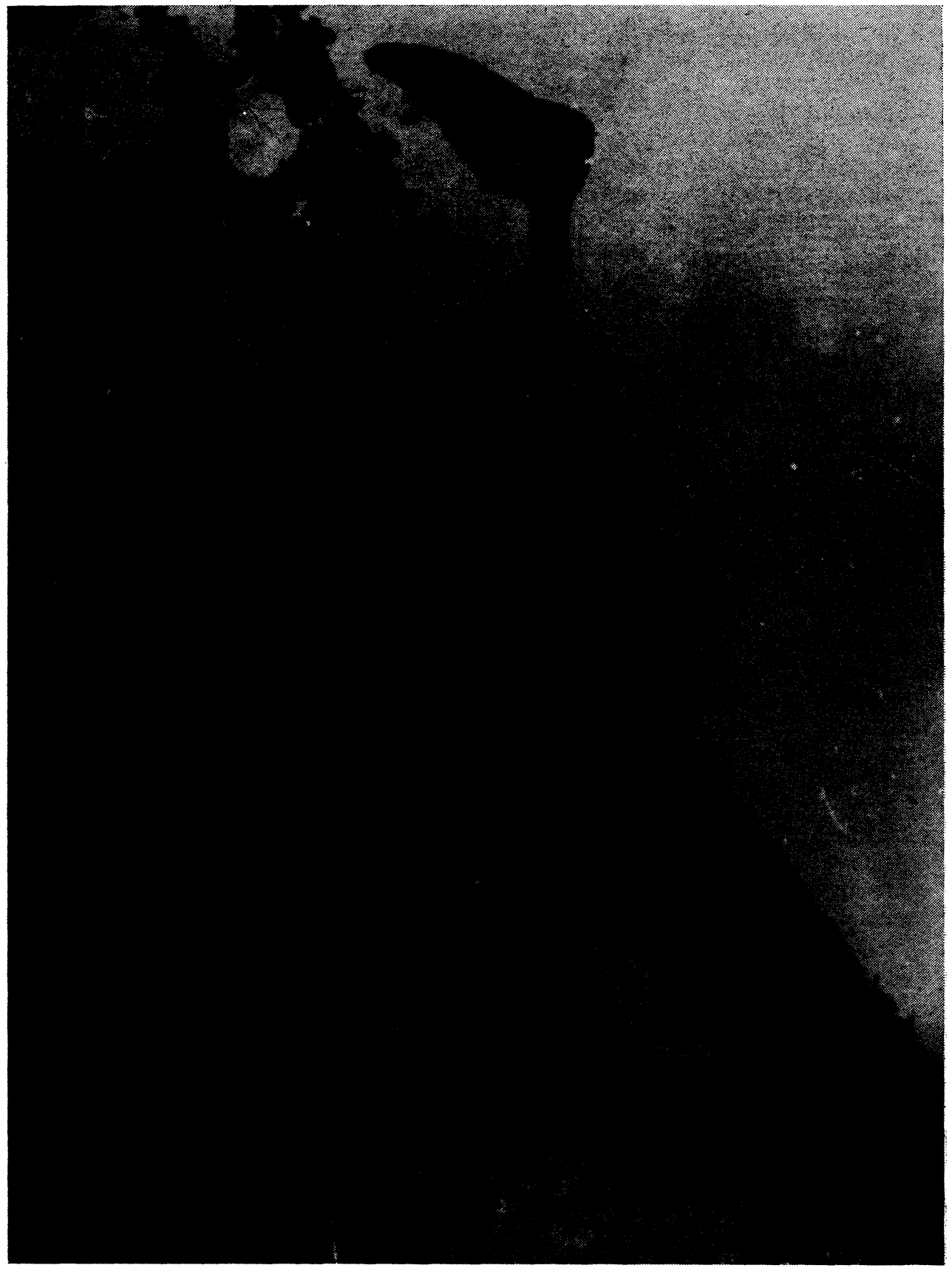

Fig. 9.

Surface of synovial membrane in ochronosis partly covered by synovial matrix (s) with penetrating erythrocytes (b). Between cytoplasmic processes the ground amorphous substance predominates. $11400 \times$. 


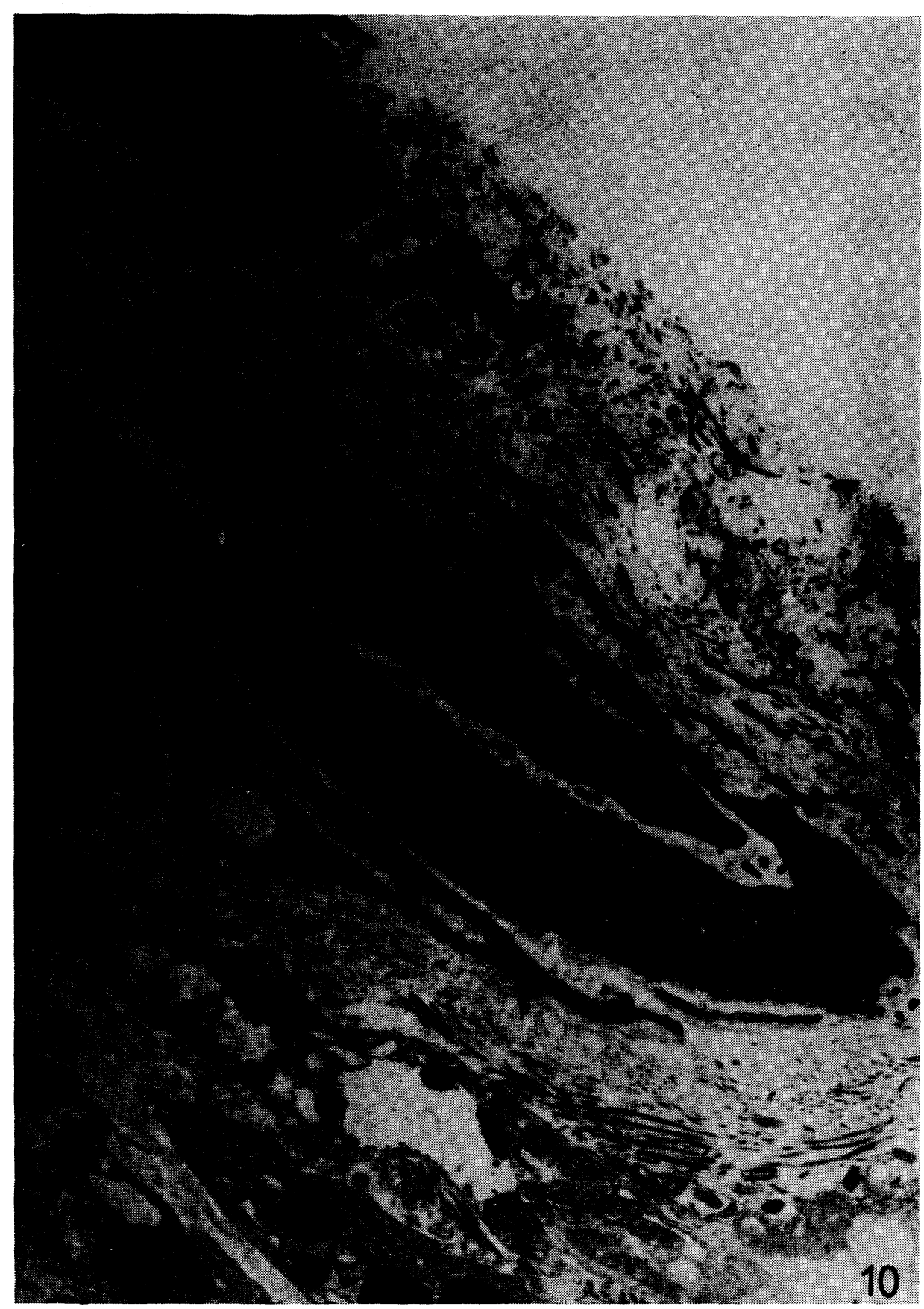

Fig. 10.

Surface of synovial membrane in ochronosis is covered by the intercellular substance with numerous collagen fibres $(\mathrm{K})$ some of which are revealed. In the intercellular substance granules of ochronotic pigment (O) deposited extracellularly, in the cytoplasm of transitory types of synovialocytes deposits of this pigment. Near the surface of the synovialis blood capillary (KK). $11400 \times$. 


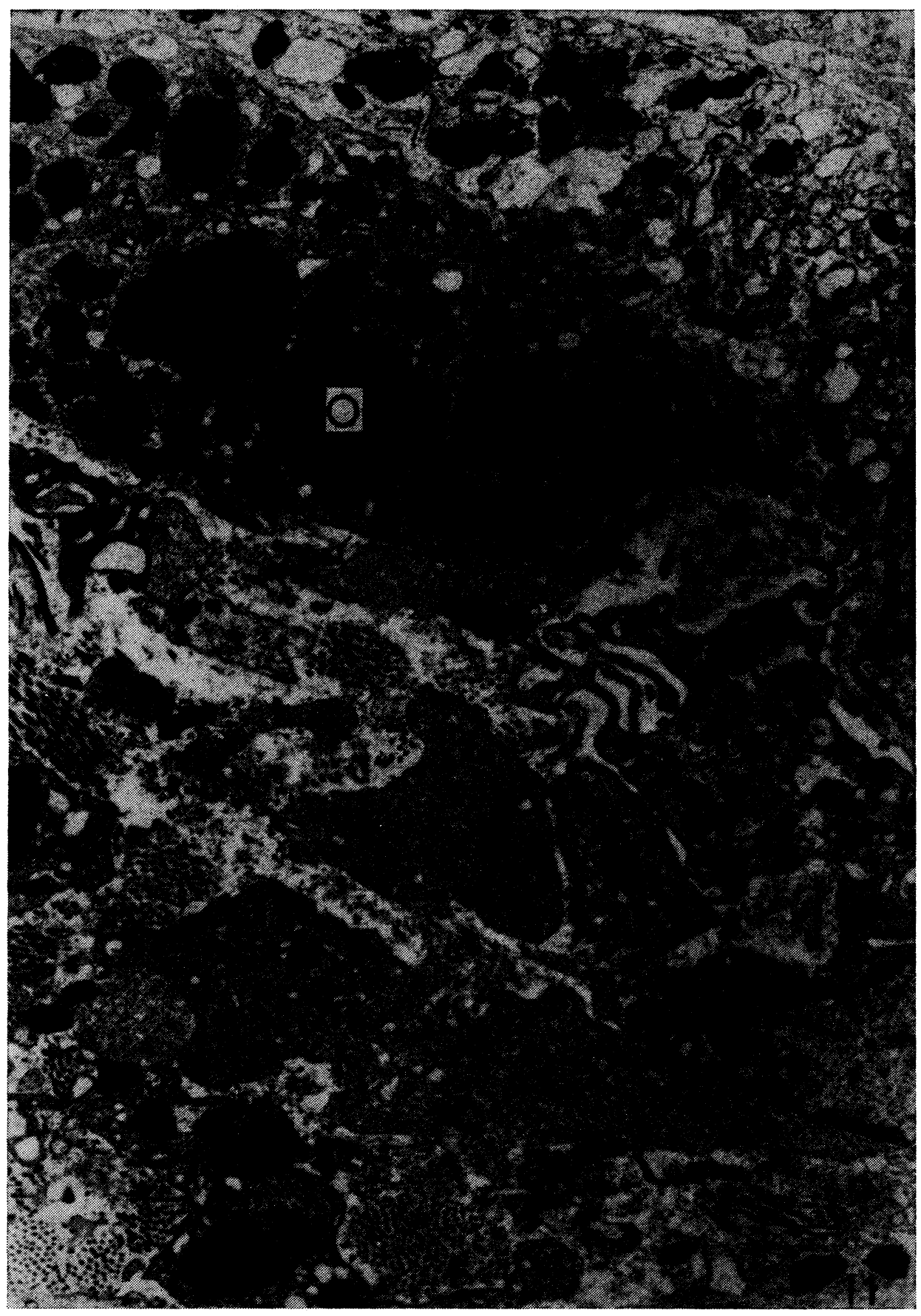


ovialocytes characterized by an expressive phagocytotic activity (Fig. 11). The cell population is formed by transitory types having some common traits of both definitely formed types. Mainly in the cytoplasm of these transitory types large amounts of ochronotic pigment are deposited. Pigment clusters are $0.1-2 \mu \mathrm{m}$ in size and in some cases it cannot be reliably proved if they are enclosed by a membrane. They consist of a granulated electron-dense material and sometimes a mass of different electron density can be observed in the same granule (Fig. 11). In several cells, damaged organelles are visible. Dilatation of cisternae of the granular endoplasmic reticulum, fragmentation of mitochondria and pyknosis of the nucleus occur. In cells resembling fibroblasts from the superficial layer pigment granules occur only scarcely (Fig. 10). Very interesting is the fact that no extracellularly deposited pigment granules occur in the intercellular substance of the synovialocyte layer. This is supported by the fact that the pigment penetrating into the ground substance of the synovial membrane is phagocytized by the synovial cells and is deposited in their cytoplasm (Fig. 11).

As in the normal synovial membrane the subsynovial tissue is of a fibrous type. In the cytoplasm of fibrocytes of the subsynovial type granules of ochronotic pigment occur in much smaller amounts than in the synovialocytes themselves (Fig. 11).

A very interesting finding is also the presence of blood capillaries near the synovial membrane surface not observed in normal synovialis (Fig. 10). According to the author's opinion their occurrence in this area is a sign of an inflammatory reaction taking place as a consequence of irritation of the synovial membrane in accompanying arthrosis.

\section{Surface of synovial membrane in a scanning electron microscope}

The appearance of the synovial membrane in ochronosis, even under medium enlargement in a scanning electron microscope, is that of a conspicuous villous tissue. On its surface numerous villous processes are evident among which deep depressions can be observed. On their bottom the cellular debris is deposited. Infrequent free cells are attached to the surface of the synovial membrane, probably from the synovial fluid (Fig. 12).

In detail it can be observed that the surface of the individual villi is very uneven. Along with regions with no major unevennesses which probably correspond with parts covered by the intercellular substance (see studies in the transmission electron microscope) numerous nipple-like excrescences protrude above the surface of the villi giving the surface of the individual folds very often an even cauliflower-like appearance. Similar formations can be observed in the incisions between the individual villi of the synovial membrane. Their basis are most probably the point-like processes of the synovial membrane evident in the transmission electron microscope and the protruding parts of synovial cells projecting towards the joint cavity. The fact that only a very few cellular elements or debris occur on the surface of the synovial membrane can be explained in that they were removed in preparation of this material.

Fig. 11.

Parts of cytoplasm of several cells of transitory type and fibrocytes of synovial membrane in ochronosis. The cytoplasm of transitory cell types (A) with deposits of ochronotic pigment $(\mathrm{O})$, damaged mitochondria $(M)$. In the cytoplasm of fibrocytes $(F)$ granules of ochronotic pigment occur only scarcely. $11000 \times$. 


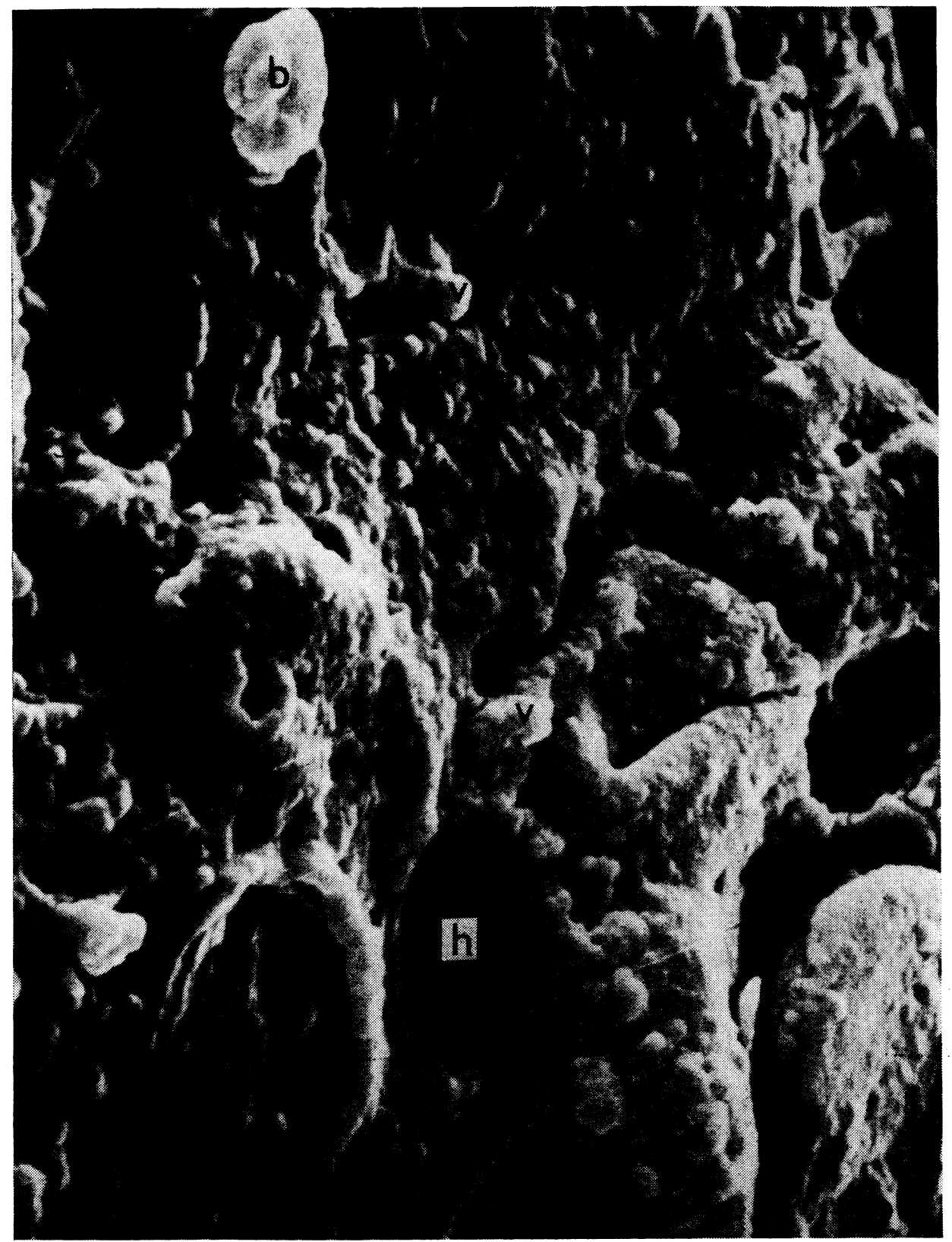

Fig. 12.

Part of surface of villi of synovial membrane in ochronosis. Numerous nipple-like processes (v) protrude above the surface to which are attached frec cells $(b)$. Between the villi deep depressions $(h)$ and furrows. Scanning electron microscopy. $30000 \times$. 
It can be stated that in the scanning electron microscope the synovial membrane appears as a strongly villous tissue, as can also be observed in other affections connected with their irritation by a inflammatory process which, in this case, occurs in ochronotic arthrosis.

\section{Discussion}

The results of the present study of the ultrastructure of the cartilage and synovial membrane can be compared with only a few studies dealing with this problem and bringing basic information about the ultrastructure of chondrocytes, intercellular substance, cells and matrix of the synovial membrane. Such are the studies of Hirohato and Morimoto (1971), Pages and Baldet (1971), Kutty et al. (1973, 1974), Reginato et al. (1973), and Bozděch et al. (1975). Along with these they are the studies of Fuchs (1968), however, dealing only with the ultrastructure of ochronotic pigment. Results of the present study of changes occurring in the ultrastructure of the cartilage are in accordance with data published above all by Pages and Baldet (1971) and Kutty et al. (1974). When comparing the findings, however, one basic problem arises considerably reducing the possibilities of mutual comparison. The above mentioned authors do not distinguish the individual layers of the cartilage when describing the results of their observations neither in their documentation and they give their findings summarized.

As far as the ultrastructure of chondrocytes is concerned, our findings correspond with the observations of Kutty et al. (1974) in proving granules of ochronotic pigment in their cytoplasm; however, in comparison with the authors mentioned above we did not find such enormous pigment deposits which fill up virtually the whole cytoplasm and which are in size and appearance comparable with deposits of this pigment in the synovial membrane. If the ochronotic pigment did occur in our material in the cytoplasm of the chondrocytes it was present in the form of individual vacuoles filled up with granular material. Even though the occurrence of lipid droplets was observed, we cannot agree with the findings of Kutty et al. (1974) who state that lipid droplets are very often present in the cytoplasm of the chondrocytes and also are attached on the outside to the cell membrane. The authors mentioned above also give the occurrence of a large number of degenerating and necrotic chondrocytes. On the basis of results of our observations we can only state that signs of degeneration of chondrocytes can be observed already in the middle layer. These signs are more frequent and more expressive in the deep layer; however, no massive occurrence of degenerating cells was found. According to Kutty et al. (1974) the degeneration of chondrocytes is caused by an accumulation of oxidized ochronotic pigment which further evokes a disorder of the metabolic activity of chondrocytes appearing first of all in the degeneration of the nucleus. However, they do not cite their opinions in data published so that they must be considered to be hypotheses. Even though signs of pyknosis of the nucleus did also occur in our material the changes in its structure do not reach such a high level as stated by Kutty et al. (1974). In accordance with data of these authors no accumulation of intracytoplasmic filaments was observed in the chondrocytes of the ochronotic cartilage; according to Meachim (1967, 1969), Meachim and Stockwell (1973), Weis and Mirrow (1972) it is one of the signs of degeneration of chondrocytes in the normal cartilage. This circumstance would thus prove the opinion of Kutty et al. (1974) about the damaged metabolism of chondrocytes in ochronosis. 
According to our findings as well as those of Pages and Baldet (1971), Jaffe (1972), Kutty et al. (1973, 1974), Reginato et al. (1973) the ochronotic pigment is localized mainly in the intercellular substance of the cartilage. Our findings correspond with published data as far as the appearance of pigment granules and their distribution are concerned, when the largest amount is deposited in the intercellular substance, whereas in the pericellular matrix their amount is considerably lower. In contradistinction to data of Kutty et al. (1974) we found granules of pigment in the close proximity of the cell membrane of chondrocytes only singularly. From the studies of Pages and Baldet (1971), Kutty et al. (1974) as well as from our observations it follows that the appearance of the ochronotic pigment deposited in the intercellular substance can vary. On the one hand it occurs in amorphous form deposited between the bundles of collagen fibres thus forming relatively thick layers, on the other hand in the form of granules of a size of as much as $1 \mu \mathrm{m}$. Our observations of the localization and appearance of the ochronotic pigment fully correspond with the observations above all of Kutty et al. (1974). However, we cannot prove their data on the disappearance of periodicity of collagen fibres in the case when they are overcovered by the ochronotic pigment. These authors most probably observed aperiodic collagen fibres in the proximity of pigment foci.

In all the studies published we completely lack data on the arrangement of the ground fibrillar substance and formation of the surface of the cartilage so that we cannot confront our observations. The situation is the same as far as scanning electron microscopy is concerned where our data published are original. When comparing findings obtained with transmission electron microscopy and scanning electron microscopy it can be stated that they are in good accordance and many structures observed in the transmission electron microscope are fully correlated with observations of the surface. The only exception is the presence of crystals of ochronotic pigment on the surface of the cartilage, evident in the scanning electron microscope, whereas on electronograms from the transmission electron microscope they were not observed. Most probably they disappeared during the preparation of the material.

The ultrastructure of the synovial membrane in ochronosis could be compared only with data given by Hirohata and Morimoto (1971), Kutty et al. (1973, 1974), Reginato et al. (1973) and with the author's previous findings (Bozděch et al. 1975). In accordance with results published deposits were found of ochronotic pigment in changed A cells of the synovial membrane by which the pigment is devoured and deposited in their cytoplasm. Also Reginato et al. (1973), Kutty et al. $(1973,1974)$ proved the extracellular occurrence of pigment granules. In accordance with our findings the latter state that the amount of pigment deposited extracellularly in the synovial membrane is evidently lower than in the intercellular substance of the cartilage. However, in the studies mentioned above there is no mention of the different regional arrangement of the synovial membrane as far as the appearance and arrangement of cells is concerned and neither of the fact that some parts of the synovialis in ochronosis do not contain pigment granules. This fact could have remained unobserved or the authors deliberately devoted their attention only to those parts where pigment occurred in large amounts. We consider the fact that in the synovial membrane in ochronosis areas occur which appear similar to the normal synovial membrane to be important because, according to our opinion, it demonstrates the different reaction ability of this tissue. According to the opinion of some authors (Jaffe 1972; 
Kutty et al. 1973, 1974) and according to our findings published earlier (Bozděch et al. 1975) the ochronotic pigment is deposited first of all into the intercellular substance of the cartilage. A similar localization of condensed product was proved by Bondurant and Henry (1965) in experimental ochronosis in rats and by Mihatsch et al. (1973) in humans. Deposits of ochronotic pigment evoke the fibrillation of the intercellular substance mass and decrease of the synthetic activity of chondrocytes in those cases when accumulation of pigment granules occurs in their cytoplasm (Kutty et al. 1974). Due to damaging of the structure of the intercellular substance serious arthrosis origins and the pigment is loosened from the damaged cartilage, transfered into the synovial fluid and is phagocytized by cells of the synovial membrane and deposited in their cytoplasm (Reginato et al. 1973; Kutty et al. 1974). Mainly the A cells are phagocytic as was also proved experimentally (Ball et al. 1964; Cochrane et al. 1965; Webb et al. 1969; Bhawan et al. 1973, Bhawan and Roy 1974; Chiu 1975). The A cells change their ultrastructure and transitory types origin, very often resembling macrophages, as they are sometimes designated in literature. They are the most frequent in the synovial membrane as was accordingly with our findings observed also by Hirohata and Morimoto (1971), Kutty et al. (1973, 1974), Reginato et al. (1973), Bozděch et al. (1975), whereas B cells either occur very scarcely or are also changed into the transitory type. In our material we did not prove any fragment of cartilage in the synovial membrane as was stated by Hirohata and Morimoto (1971) on the basis of observations in the scanning microscope and by Kutty et al. (1973) in the electron microscope. As we did not study the synovial fluid of the ochronotic joint we cannot express our view about the data of Reginato et al. (1973) about the occurrence of granules of ochronotic pigment and fragments of the cartilage in the joint liquid. In accordance with the above mentioned authors the largest amount of pigment was found in the middle layer of cells of the synovial membrane, whereas in the subsynovial tissue there is a much smaller amount of pigment in the cells. It is interesting that even though the cells of the synovial membrane contain large deposits of ochronotic pigment no signs of degeneration of these cells were proved as can be observed in chondrocytes where there is a much smaller amount. This fact would agree with the opinion of Kutty et al. $(1973,1974)$ that the pigment in chondrocytes is formed by partial oxidation of homogentisic acid as follows from its tinction properties whereas by cells of the synovial membrane it is merely phagocytized. However, the oxidation of homogentisic acid in the cytoplasm of chondrocytes has not been sufficiently proved even though numerous studies were published on the biochemical release of tyrosine because the chemical composition of ochronotic pigment is not yet quite known (Jaffe 1972; Bozděch et al. 1975). It is supposed that it is a polymer of homogentisic acid because the impregnation of tissue with this substance is still reversible, whereas ochronotic pigment is deposited permanently in the tissue. With regard to pigment and its composition in the various types of tissue this problem was studied by Fuchs (1968) who proved that it is a substance containing no iron, is composed of granules of a size of about $40 \mu \mathrm{m}$, forming clusters of as much as $1 \mu \mathrm{m}$ in diameter. These data fully correspond with our findings.

The synovial membrane has not yet been studied in a scanning electron microscope and we had no opportunity to confront the results of our observations with published data. Nevertheless, when comparing the results from transmission 
electron microscopy it follows that the villous formations observed in the scanning electron microscope correspond to the large processes, and the small nipple-like processes correspond most probably to the protruding cells of the synovial membrane or with their processes observed in the transmission electron microscope. The basis of large irregularities are bundles of collagen fibres deposited in the close proximity of the surface of the synovial membrane and in the case of their uncovering due to the disappearance of the ground amorphous substance they protrude above the surface. Under small and medium enlargements used in scanning electron microscopy and demonstration of a relatively large area of tissue we see the plasticity of the villous surface of the synovial tissue which, in ochronosis, reacts to the arthrotic process and especially through the phagocytotic activity of cells participates on the removal of cell debris and ochronotic pigment from the joint cavity.

\section{Submikroskopická struktura kloubní chrupavky a synoviální membrány člověka při ochronose}

V práci byla transmisním elektronovým a rastrovacím elektronovým mikroskopem studována kloubní chrupavka a synoviální membrána 5 jedinců ve stárí 30-55 let.

Povrchová vrstva chrupavkyi $\mathrm{z}$ větši části chybí $\mathrm{v}$ důsledku artrotických změn, způsobených ukládáním granul ochronotického pigmentu $\mathrm{v}$ mezibuněčné hmotě chrupavky. $\mathrm{V}$ okrscích se zachovanou chrupavkou jsou na jejím povrchu zřetelné známky artrosy. V cytoplasmě chondrocytů střední vrstvy se objevují váčky vyplněné ochronotickým pigmentem v rưzném stadiu polymerisace. Dochází ke zmnožení aperiodických vláken, která pronikají do blízkosti chondrocytů, takže vymizí pericelulární matrix. Do této oblasti se ukládají granula ochronotického pigmentu $\mathrm{v}$ malém počtu, zatímco $\mathrm{v}$ intercelulární matrix se vyskytují ve značném množství jednak $\mathrm{v}$ podobě granul, jednak ve vrstvách, uložených mezi tlustými kolagenními vlákny. V hluboké vrstvě se objevují známky degenerace chondrocytů. V cytoplasmě se vyskytují autofagické vakuoly, tvořené granuly pigmentu, sekundárními lysosomy, tukovými kapénkami a koncentricky vrstvenými membránami granulovaného endoplasmatického retikula. $\mathrm{V}$ rastrovacím elektronovém mikroskopu jsou zřetelně patrny hluboké defekty na povrchu a prázdná pouzdra chondrocytů $s$ valovitě konturovanými okraji. Jak na dně těchto pouzder, tak na povrchu chrupavky jsou uloženy krystaly ochronotického pigmentu, buněčný detritus a ojedinělé buňky. Krátké úseky synoviální membrány jsou kryty souvislou vrstvou buněk přechodného typu. $\mathrm{V}$ takto uspořádané synoviální membráně se nevyskytuje pigment. Převážná část synoviální membrány je kryta vrstvou mezibuněčné hmoty, $v$ níž jsou uložena granula ochronotického pigmentu. Bliže povrchu se synovialocyty podobaji fibrocytům a $\mathrm{v}$ jejich cytoplasmě se vyskytují granula pigmentu v malém počtu. Hlouběji uložené synovialocyty jsou intermediárního typu a $\mathrm{v}$ jejich cytoplasmě dochází $\mathrm{k}$ ukládání pigmentu v podobě velkých deposit velikosti až $2 \mu \mathrm{m}$. 


\section{Субмикроскопическая структура суставного хряща и синовиальной мембраны при охронозе у человека}

С помощью трансмиссионного электронного и растрового электронного микроскопов проводились исследования суставного хряща и синовиальной мембраны 5 человек в возрасте 30-55 лет.

В результате отложения гранулей охронотического пигмента в межклеточной массе хряща поверхностный слой хряща болышей часьтю отсутствует. На участках с сохранившимся хрящом на его поверхности заметны следы артроза. В цитоплазме хондроцитов среднего слоя появляются мешочки, наполненные охронотическим пигментом на разной стадии полимеризации. Имеет место увеличение апериодических волокон, проникающих непосредственно к хондроцитам, в результате чего исчезает околоклеточный слой. В данной области происходит отложение гранулей охронотического пигмента в небольшом количестве, между тем как межклеточный слой отличается их большим количеством в форме гранулей, а также в слоях, образовавшихся между толстыми коллагенными волокнами. В глубоком слогө появляются признаки дегенерации хондроцитов. В цитоплазме имеют место аутофагические вакуоли, образуемые гранулами пигмента, вторичными лизосомами, жировыми капельками и концентрически расслоенными мембранами гранулированной эндоплазматической сетчатой ткани. В растровом электронном микроскопе явны гдлубокие дефекты на поверхности и сумки хондроцитов с валообразными контурами по краям. На дне упомянутых сумок и на поверхности хряща расположены кристаллы охронотического пигмента, клеточный детрит и отдельные клетки. Короткие участки синовиальной мембраны прикрыты цельным слоем клеток переходящего типа. В расположенной таким образом синовиальной мембране нет пигмента. Ее преобладающая часть прикрыта слоем межклеточной массы, в которой находятся гранули охронотического пигмента. Ближе к поверхности синовиалоциты похожи на фиброциты и гранули пигмента в их цитоплазме находятся в небольшом количестве. Глубже расположенные синовиалоциты являются интермедиарного типа и в их цитоплазме происходит отложение пигмента в форме крупных отложений величиной до 2 мкм.

\section{References}

ATTWOOD, H. D. - CLIFTON, S. - MITCHEL, R. E.: A histological, histochemical and ultrastructural study of dermal ochronosis. Pathology 3, 1971: 115-121.

BONDURANT, R. E. - HENRY, J. B.: Pathogenesis of ochronosis in experimental alkaptonuria of the white rat. Lab. Invest., 14, 1965: 62-64.

BOZDĚCH, Z. - HORKÝ, D. - HORN, V.: Nové poznatky o ochronóze. Acta Chir. orthop. Traum. Cech., 42, 1975: 39-38.

COOPER, J. A. - MORAN, T. J.: Studies on ochoronosis. Arch. Path., 64, 1957: 46-53.

DAICKER, B. - RIEDE, U. N.: Histological and ultrastructural findings in alkaptonuria ocular ochronosis. Opthalmologica, 169, 1974: 377-388.

FASSBENDER, H. C. - ISOMAKI, M. - HAAPASAARI, J.: Histopathology of the joint. Scand. J. Rheumatol. Suppl., 12, 1975: 114-115.

FUCHS, U.: Electron microscopic study of the homogentisic acid melanin in ochronosis. Virchows Arch. Abt., A 344, 1968: 243-248.

GARROD, A. E.: Inborn errors of metabolism. H. Frowde, Hodder and Stoughton, eds., London, 1923.

HIROHATA, K. - MORIMOTO, K.: Ultrastructure of bone and joint diseases. Tokyo: Igaku Shoin Ltd., Excerpta medica, Amsterodam, 1971.

KUTTY, M. K. - IQBAL, G. M. - TEH, E. C.: Ochronotic arthropathy. Arch. Pathol., 96, 1973: 100-103. 
KUTTY, M. K. - IQBAL, G. M. - TEH, E. C.: Ochronotic arthropathy: an electron microscopical study with a view on pathogenesis. Arch. Pathol., 98, 1974: 55-57.

La DU, B. N. - ZANNONI, V. G. - LASTER, L. - SEEGMILLER, J. E.: The nature of the defect in tyrosine metabolism in alkaptonuria. J. Biol. Chem., 230, 1958: 251-260.

La DU, B. N. - O'BRIEN, W. M. - ZANNONI, V. G.: Studies on ochronosis. I. The distribution of homogentisic acid in guinea pigs. Arthritis Rheum, 5, 1962: 81-87.

LASKAR, F. M. - SARGISON, K. D.: Ochronotic arthropathy. J. Bone Jt Surg., 52 B, 1970: 653-666.

LICHTENSTEIN, L. - KAPLAN, L.: Hereditary ochronosis. Am. J. Path., 30, 1954: 99-125.

McCOLLUM, D. E. - ODOM, G. L.: Alkaptonuria, ochronosis and lowback pain. J. Bone Jt Surg., 47 A, 1965: 1388-1392.

MEACHIM, G.: The histology and ultrastructure of cartilage. In: Proceedings of a workshop on cartilage. C. A. L. Basset, ed., Washington D. C.: National Research Council, 1967.

MEACHIM, G.: Age changes in articular cartilage. Clin. Orthop., 64, 1969: 33-44.

MEACHIM, G. - STOCKWELL, R. A.: The matrix. In: Adult articular cartilage. M. A. R. Freeman, ed., Great Britain, Alden Press, Oxford, 1973.

MIHATSCH, M. J. - RIEDE, U. N. - BIANCHI, L.: Ultrastructure of cartilage in phenacetine pseudo-ochronosis and alkaptonuria. Virchows Arch. A Zellpathol, 14, 1973: 307-312.

O'BRIEN, W. M. - HANDLEY, C. J.: The ultrastructural morphology and biochemistry of chick embryo chondrocytes in culture. Amer. J. Anat., 118, 1974: 390 - 391 .

OPPENHEIMER, B. S. - KLINE, B. S.: Ochronosis. Arch. Int. Med., 29, 1922: 732-747.

PAGES, A. - BALDET, P.: Ochronosis-anatomoclinical and electron microscopic aspects. Ann. Anat. Pathol., Paris, 16, 1971: 27-46.

POPE, F. M.: A case of ochronosis. Lancet, 1, 1906: 24.

POULSEN, V.: Om ochronotiske tilstande hos mennesker og dyr. Thesis on chronosis. Copenhagen, Lund, 1910.

REGINATO, A. J. - SCHUMACHER, H. R. - MARTINEZ, V. A.: The articular cartilage in familial chondrocalcinosis: light and electron microscopic study. Arthritis Rheum, 16, 1973: $127-128$.

WEISS, C. - MIRROW, S.: An ultrastructural study of osteoarthritic changes in the articular cartilage of human knees. J. Bone Jt Surg., 54 A, 1972: 954-972. 